\title{
Pseudomonas aeruginosa Resistance to Bacteriophages and Its Prevention by Strategic Therapeutic Cocktail Formulation
}

\author{
Andrew Vaitekenas ${ }^{1,2}\left(\mathbb{D}\right.$, Anna S. Tai ${ }^{3,4,5}$, Joshua P. Ramsay ${ }^{6}$, Stephen M. Stick ${ }^{2,7,8,9}$ \\ and Anthony Kicic $1,2,7,8,9, *$ (D)
}

1 Occupation and the Environment, School of Public Health, Curtin University, Perth, WA 6102, Australia

2 Wal-Yan Respiratory Research Centre, Telethon Kids Institute, The University of Western Australia, Crawley, WA 6009, Australia; andrew.vaitekenas@telethonkids.org.au (A.V.);

Stephen.Stick@health.wa.gov.au (S.M.S.)

3 Department of Respiratory Medicine, Sir Charles Gairdner Hospital, Perth, WA 6009, Australia; Sze.Tai@health.wa.gov.au

4 Institute for Respiratory Health, Perth, WA 6009, Australia

5 Faculty of Health and Medical Sciences, The University of Western Australia, Perth, WA 6009, Australia

6 Curtin Medical School and Curtin Health Innovation Research Institute, Curtin University,

Perth, WA 6102, Australia; josh.ramsay@curtin.edu.au

7 Division of Paediatrics, School of Medicine, The University of Western Australia, Perth, WA 6009, Australia

8 Department of Respiratory and Sleep Medicine, Perth Children's Hospital, Perth, WA 6009, Australia

9 Center for Cell Therapy and Regenerative Medicine, School of Medicine and Pharmacology, The University of Western Australia and Harry Perkins Institute of Medical Research, Perth, WA 6009, Australia

* Correspondence: Anthony.Kicic@telethonkids.org.au; Tel.: +(61)-8631-91799

Citation: Vaitekenas, A.; Tai, A.S.; Ramsay, J.P.; Stick, S.M.; Kicic, A.

Pseudomonas aeruginosa Resistance to Bacteriophages and Its Prevention by Strategic Therapeutic Cocktail Formulation. Antibiotics 2021, 10, 145. https: / / doi.org/10.3390/

antibiotics10020145

Academic Editor:

Giovanni Bonaventura

Received: 23 December 2020

Accepted: 27 January 2021

Published: 2 February 2021

Publisher's Note: MDPI stays neutral with regard to jurisdictional claims in published maps and institutional affiliations.

\section{Copyright: (c) 2021 by the authors.} Licensee MDPI, Basel, Switzerland. This article is an open access article distributed under the terms and conditions of the Creative Commons Attribution (CC BY) license (https:// creativecommons.org/licenses/by/ $4.0 /)$.

\begin{abstract}
Antimicrobial resistance poses a significant threat to modern healthcare as it limits treatment options for bacterial infections, particularly impacting those with chronic conditions such as cystic fibrosis (CF). Viscous mucus accumulation in the lungs of individuals genetically predisposed to CF leads to recurrent bacterial infections, necessitating prolonged antimicrobial chemotherapy. Pseudomonas aeruginosa infections are the predominant driver of CF lung disease, and airway isolates are frequently resistant to multiple antimicrobials. Bacteriophages, or phages, are viruses that specifically infect bacteria and are a promising alternative to antimicrobials for CF P. aeruginosa infections. However, the narrow host range of $P$. aeruginosa-targeting phages and the rapid evolution of phage resistance could limit the clinical efficacy of phage therapy. A promising approach to overcome these issues is the strategic development of mixtures of phages (cocktails). The aim is to combine phages with broad host ranges and target multiple distinct bacterial receptors to prevent the evolution of phage resistance. However, further research is required to identify and characterize phage resistance mechanisms in CF-derived P. aeruginosa, which differ from their non-CF counterparts. In this review, we consider the mechanisms of $P$. aeruginosa phage resistance and how these could be overcome by an effective future phage therapy formulation.
\end{abstract}

Keywords: phage resistance; bacteriophages; Pseudomonas aeruginosa; cystic fibrosis; phage therapy

\section{Introduction}

The increased rate of antimicrobial resistance in human and animal pathogens presents the prospect of a post-antibiotic era, prompting the World Health Organization (WHO) to compile a list of priority antimicrobial-resistant pathogens requiring the development of alternative antimicrobials [1]. Despite the urgency, economic hurdles have led to a paucity in the development of new antimicrobials, leaving fewer drugs to treat priority multi-resistant pathogens such as Acinetobacter baumannii, Pseudomonas aeruginosa, and Enterobacteriaceae [2,3]. Without drastic action to combat antimicrobial-resistant infections, they are predicted to be the primary cause for up to 10 million deaths globally by 2050 and the associated loss in gross domestic product is USD 100 trillion [4]. The burden of 
antimicrobial-resistant infections will be greatest in individuals with chronic conditions, as they are disproportionately affected by bacterial infections [5]. Amongst these are people with cystic fibrosis (CF), who are predisposed to recurrent and persistent bacterial infections. CF is caused by mutations in the Cystic Fibrosis Transmembrane Conductance Regulator (CFTR) gene. Mutations result in dehydration of the air surface liquid on airway epithelial cells [6], leading to defective mucociliary clearance and the concentration of viscous mucus within the airways [7]. The viscous and stagnant mucus of the CF lung microenvironment is conducive to bacterial attachment and propagation [8] and ensuing bacterial infections stimulate inflammation, irreversible structural lung changes, damage, and functional decline in the lungs, collectively known as progressive lung disease [9-11]. Prolonged and recurrent bacterial infections lead to respiratory failure, which is the most common cause of death in those with CF [12,13].

\section{Pseudomonas aeruginosa and CF}

P. aeruginosa is widely considered the most important bacterial infection in CF, as its associated inflammation drives lung disease progression and, ultimately, mortality $[10,11,14-18]$. Infections begin with a period of intermittent isolation in children, typically $2-3$ years of age, but can occur much earlier in life, even by 3 months of age $[19,20]$. Early intermittent colonisations are typically caused by environmental $P$. aeruginosa isolates [21], which commonly exhibit a non-mucoid colony morphology and are usually motile and virulent but still susceptible to antimicrobials [22,23]. However, widespread P. aeruginosa strains (epidemic strains) can also be significant sources of infection and antimicrobial resistance [24-30]. Eradication of P. aeruginosa following each infection is attempted to prevent chronic colonisation and airway damage [31-37]. Nevertheless, vigilant detection, aggressive eradication, and infection control strategies are successful in delaying, but not preventing, the eventual establishment of chronic P. aeruginosa in the CF airway $[13,38]$.

Once a CF patient is persistently colonised with established P. aeruginosa populations, they often form antimicrobial-resistant biofilms [39]. Additionally, despite arising from a clonal population, persistent $P$. aeruginosa populations diversify through mutation [40]. The diversification process is frequently accelerated via hypermutable sub-populations of cells with deficits in DNA repair systems [41-44]. However, features typically exhibited by persistently infecting strains include high antimicrobial resistance, mucoid colony morphology, and attenuated motility and virulence [45]. These adaptations likely contribute to $P$. aeruginosa being the most common persistently colonising pathogen in adults with $\mathrm{CF}$, where $80 \%$ are chronically infected [38]. To treat antimicrobial-resistant infections, clinicians must use last resort antimicrobials, cocktails, and high drug concentrations that present safety issues $[46,47]$. Current strategies are not viable long-term solutions for CF treatment in the post-antibiotic era and alternative antimicrobials are urgently required.

\section{Phage Therapy}

Bacteriophages (phages) are viruses that specifically infect bacteria and present an alternative treatment strategy to antimicrobials. Phages bind to specific receptors on the bacterium surface, inject their genome, self-replicate using the host cell machinery, and lyse the bacterium to release progeny [48]. Phages have a long history of use, especially in Eastern European countries where early proof of principle trials were performed and phage therapy is still practised today [49]. Despite the early trials of phage therapy often being successful, there were also notable treatment failures due to technological and knowledge limitations [50], leading to poorly manufactured phage therapies [51].

There are many approaches to phage therapy including single phage, phage cocktail, phage enzyme, and combination therapies, which have been reviewed previously [52]. Before a therapy is produced, phages must be isolated and characterised. Phages are isolated where their host bacteria are found $[53,54]$. Common sources include clinical infection samples, like sputum [55], or from wastewater, especially if it is collected from around hospitals [56]. Isolation of phages active against different bacterial species have 
varied in success, but $P$. aeruginosa phages tend to be the most frequently isolated [57]. Characterisation of isolated phages is essential to ensure that they exclusively exhibit a bactericidal lifecycle, are active against clinically relevant bacteria, and do not contain bacterial genes that could improve a bacterium's fitness [53,54].

Advances in synthetic biology have allowed the design of phages from previously isolated and rigorously characterised phages. These engineered entities can diversify phages available for a host bacterium without further isolation [58]; augment a phage's host range [58], including across species and genus levels [59]; prevent phage resistance [60]; and alter the action of phages that could increase their safety to humans [61]. Phage engineering has primarily used homologous recombination of a phage's genome with scaffolds in a bacterial host or the assembly of a complete phage genome from small fragments $[62,63]$. Genetic engineering through recombination has been hampered by the low recombination rates of phages $[62,63]$. However, the natural recombination sites of temperate phages have been leveraged to increase the efficiency of the process [62,63]. To identify recombinant mutant phages, extensive screening is thus required, which can be aided with a selection stage $[62,63]$. Yet, assembling small fragments into a phage genome does not necessarily require a bacterial host and, therefore, can use genes that are toxic to a bacterium and can be performed at a higher efficiency for lytic phages [62,63]. It is currently difficult to assemble large genomes and protocols are complicated or still being established for many host bacteria [62]. Genetically engineered phages offer commercialization opportunities that natural phages do not [62], but they may face extra regulatory challenges [51].

Regardless of their source, once they pass the characterisation stages of research, phages must be produced according to Good Manufacturing Practice (GMP) [51]. However, large-scale production processes can be complicated due to the biological nature of both phages and their bacterial host [64] and the lack of a complete set of phage-specific GMP guidelines [51]. There is a particular paucity in GMP guidelines for the quality control of phage therapeutics, but this can be informed by readily available information including host range, host bacterial component contamination, morphology through transmission electron microscopy, and genome sequence analysis [51].

\section{Phage Therapy for the Treatment of $P$. aeruginosa}

Numerous studies have demonstrated phage therapies' effectiveness against $P$. aeruginosa and eukaryotic tolerability in in vitro and in vivo models [65-78]. Individual phages only infect a specific subset of $P$. aeruginosa strains, so the effectiveness of phage therapy may vary greatly depending on the specific $\mathrm{CF}$ lung population. Therapy effectiveness can be improved by combining phages with a diversity of host ranges into cocktails $[65,76]$ and synergistic phage-antimicrobial cocktail therapy $[71,75,79,80]$. Initial experimental successes have led to the compassionate use of phage therapy for treatment of antimicrobialresistant infections, including $P$. aeruginosa in those with $\mathrm{CF}$, where phages have been identified as effective and safe $[49,81-83]$. However, to be more widely translated, clinical trials are required. There have been two clinical trials of phage therapy: a trial involving the treatment of P. aeruginosa ear [84] and burn infections [85]. Phage therapy was shown to be effective and safe in the relatively small trial against $P$. aeruginosa ear infections [84]. Whereas in the trial for the treatment of burn wound infections, only safety was demonstrated, since there were issues manufacturing GMP-quality phage cocktails at sufficient titre [85]. Inconsistent results necessitate additional clinical trials, not only specifically in this context, but also for the treatment of other infections, such as P. aeruginosa CF lung infections. To enable clinical trials and for phage therapy to become a standard adjunct to antimicrobials in CF, further detailed pre-clinical studies are needed.

One area requiring further investigation is the evolution of phage resistance and its suppression [86]. The importance of phage resistance has also been realised in the compassionate treatment of antimicrobial-resistant infections and necessitated rapid cocktail reformulation to prevent treatment failure [87-90]. As a result, it is important to consider $P$. aeruginosa phage resistance to ensure the efficacy of phage therapy in the long-term. 


\section{Phage Resistance}

Bacterial resistance to phages can occur at every stage of the phage lifecycle from: (i) receptor recognition and binding, (ii) genome injection, (iii) DNA replication, (iv) transcription and translation, (v) phage assembly, and (vi) phage release. The general bacterial phage-resistance mechanisms have been reviewed previously [91] and are still being discovered [92]. The evolution of bacterial resistance to phages is very rapid due to there being billions of bacteria in a single colony and the existence of resistant mutants. Likewise, phage evolution in response to bacterial changes is also rapid because 10 to $>100$ phages are released by productive infection of a host bacterium. The rapid reciprocal evolution of bacteria and phages has been explained by the Red Queen theory of evolution, where parasite and host are continually mutating, resulting in the relationship appearing static [93]. In the pursuit of understanding this host-parasite relationship, two of the most important genetic engineering technologies have been discovered, namely Clustered Regularly Interspaced Short Palindromic Repeat (CRISPR-cas) and restriction enzymes. However, in the context of phage therapy, the resistance predominantly occurs at the receptor recognition and binding stage through receptor mutations [94].

\section{P. aeruginosa Phage Resistance}

\subsection{Receptor Mutations}

Commonly identified receptors for P. aeruginosa phages are lipopolysaccharide (LPS) and type IV pili (T4P) [95], with the phage OMKO1 using OprM, which is a key component of the MexAB-OprM antibiotic efflux pump [96]. Development of resistance to OMKO1 was shown to increase antimicrobial susceptibility in an initially multi-drug-resistant strain of $P$. aeruginosa [96]. This suggests that the effect of phage resistance may be beneficial in reducing antimicrobial resistance and that combined antimicrobial-phage therapy could prevent resistance evolving to either treatment. The phage resistance mutations identified in previous studies have been summarized in Supplementary Table S1.

LPS is composed of lipid A (membrane embedded domain), a core (domain connecting lipid $\mathrm{A}$ and $\mathrm{O}-$-antigen), and O-antigen (polysaccharide that extends extracellularly). $P$. aeruginosa expresses three types of $\mathrm{O}$-antigen, which include the common polysaccharide antigen (CPA; homopolymer O-antigen), O-antigen specific (OSA; heteropolymer $\mathrm{O}$-antigen), and uncapped antigen (no or one O-antigen sugar). Therefore, resistance mutations for LPS-exploiting phages vary according to which LPS component or type the phage specifically binds (Figure 1). Mutations to T4P can occur in genes encoding structural components, therefore preventing the receptor being created or those that drive pilus retraction for twitching motility (Figure 1). Retraction of T4P is required by pili-specific P. aeruginosa phages because it allows them to meet the host membrane and continue infection [97]. Additionally, receptor mutations range from single base-pair alterations to $>100 \mathrm{kbp}$ multi-gene deletions (Supplementary Table S1). Receptor mutations can also have wider effects than the phage receptor through altering genes with multiple functions (Supplementary Table S1). In some cases, large or regulatory gene mutations may be beneficial to P. aeruginosa by providing cross-resistance to other phages, they can also result in increased fitness costs [98]. Oechslin et al. (2016) found that a phage-resistant mutant carrying a large genomic deletion had increased susceptibility to ciprofloxacin and by exploiting this via combined phageantimicrobial therapy, resistant bacterial mutants were suppressed. However, even small mutations to phage receptors, when phages are not present, have been shown to attenuate bacterial growth [78,99], biofilm formation [100,101], motility [71,78,101,102], antimicrobial resistance [71,96], virulence, and infectivity $[71,78,103]$. 


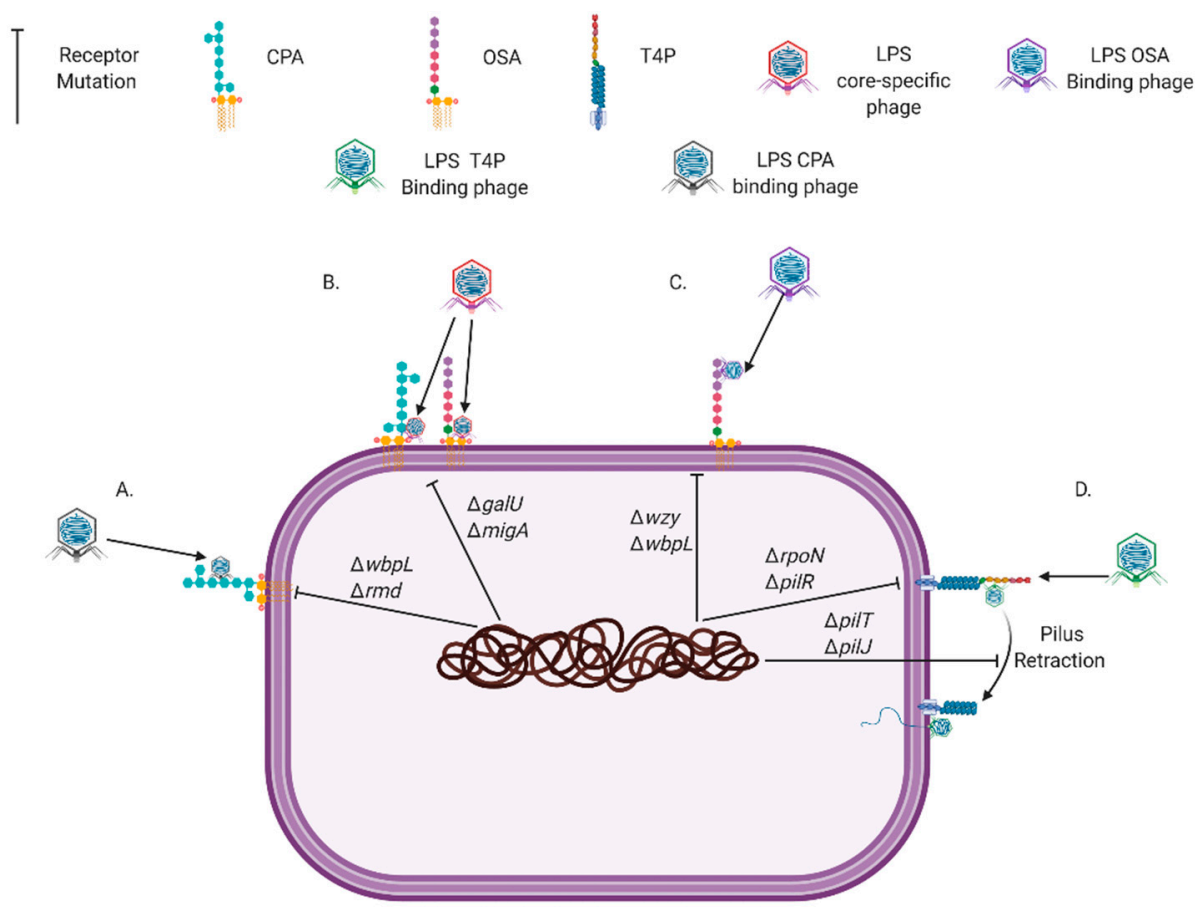

Figure 1. Common Pseudomonas aeruginosa genetic mutations that prevent the phage receptors Common Polysaccharide Antigen (CPA) (A), lipopolysaccharide (LPS) core (B), O-Specific Antigen (OSA) (C), and Type IV Pili (T4P) (D) being synthesized or functioning. Created with BioRender.com.

The strength of both phage resistance and the associated fitness cost is phage-specific [99]. Therefore, it is theoretically possible to combine phages into cocktails to provide multiple distinct selection pressures, which also comes with a maximum cost to fitness. Yang et. al. (2020) strategically formulated a cocktail of phages that successfully suppressed the evolution of resistance, but after prolonged incubation phage resistance was observed. Further suppression of phage resistance could be attained by using phages specific for more receptors, combining phages with antimicrobials, exploiting the fitness cost of phage resistance in therapeutic formulation, and including phages that kill specific resistant mutants of bacteria (escape mutants; Figure 2a). Moreover, the use of strains from non-CF origins in all but one of the studies of $P$. aeruginosa phage resistance [71] has neglected the contributions of the unique adaptions of CF clinical isolates of P. aeruginosa on phage therapy and resistance. Therefore, this paucity limits the relevance of findings to the treatment of $\mathrm{CF}$ airway infections. 
(a)

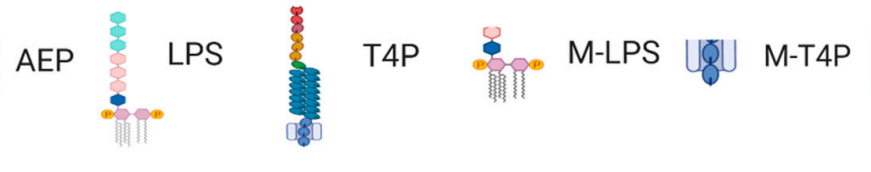

\section{DMAE} MAEP Synergistic Selection Pressure

\section{Cocktail Treatment}

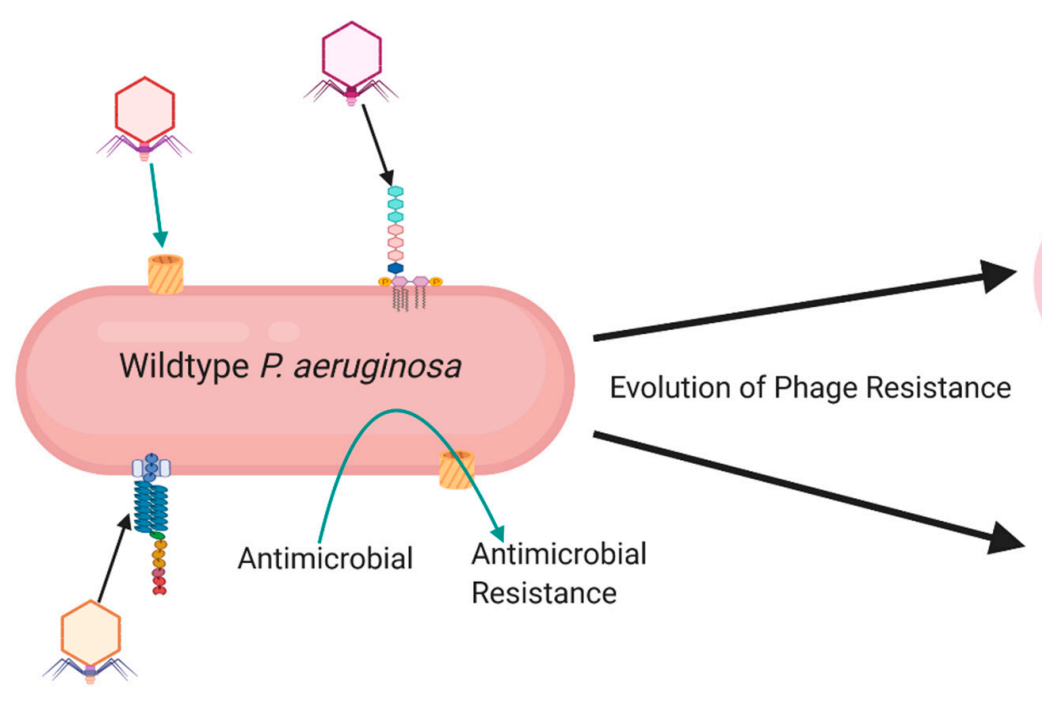

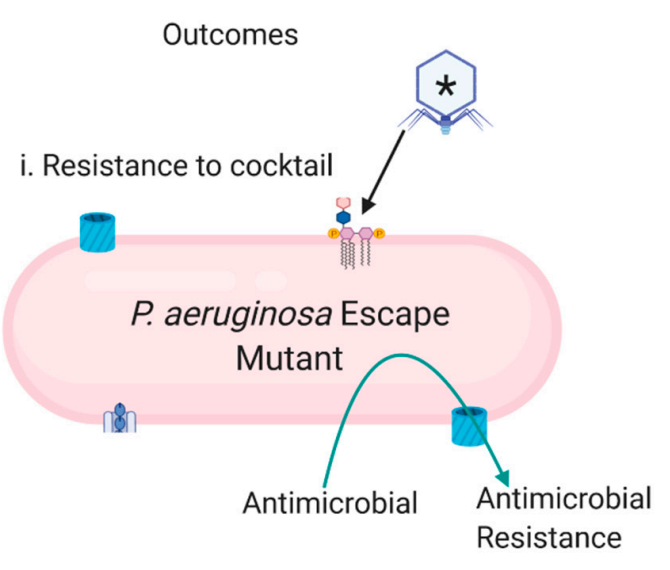

ii.Diverse Selection Pressures

+ High Fitness Cost

= Unsustainable escape mutant

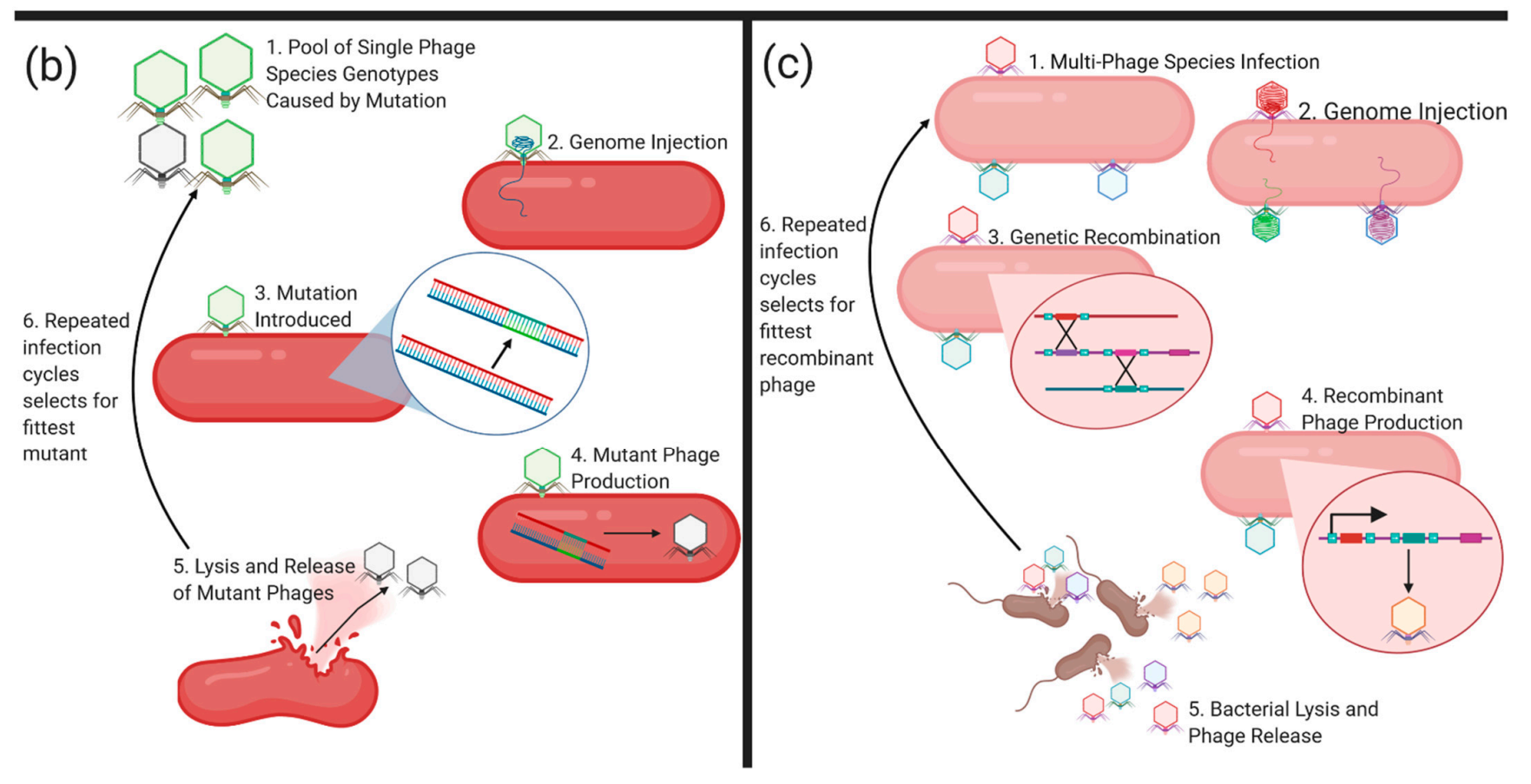

Figure 2. (a) The rationale for strategic cocktail formulation. Cocktails contain phages that use different receptors like lipopolysaccharide (LPS), type IV pili (T4P,) or antimicrobial-resistant determinants (antibiotic efflux pumps; AEP) so that their addition with antimicrobials provides opposite and synergistic selection pressures. This will result in outcome i, where resistance arises to the phage cocktail through mutations that alter the availability of phage receptors. For example, this outcome may result in a mutated LPS (M-LPS), a mutated T4P (M-T4P), and a mutated antibiotic efflux pump (MAEP) with conserved efflux function. This outcome can be prevented by adding the phage (denoted by *) to the cocktail that specifically kills the escape mutant, therefore forcing further different mutations in the bacteria, which could result in outcome ii, whereby the selection pressures are so diverse and come with a high fitness trade-off that resistance is unsustainable. (b) Phage evolution by spontaneous small mutation during DNA replication. (c) Phage evolution by genetic recombination between multiple phages. Created with BioRender.com. 


\subsection{Superinfection Systems}

Temperate phages, capable of both lysis and integration into the host bacterial genome, are abundant in CF isolates of $P$. aeruginosa $[104,105]$. Phages exhibiting temperate lifecycles are not used for phage therapy because integration into the host genome can increase P. aeruginosa virulence [104,106], antimicrobial resistance [104], and biofilm formation [105]. Temperate phages integrated into bacterial genomes can also increase host fitness by providing resistance to the subsequent phage infection, known as superinfection resistance. Mechanistically, this is achieved through the alteration of the two most common P. aeruginosa phage receptors (T4P and LPS) and production of repressors of phage infection [107]. Superinfection resistance prevents the infection of a limited range of phages, which is determined by both the temperate phage and the P. aeruginosa host [107-110]. As phage therapy does not use temperate phages, superinfection resistance can be circumvented by conducting host range experiments. The host range experiments enable the identification of lytic phages that are not resisted by the temperate phages contained in a P. aeruginosa isolate. However, due to the mobile nature of temperate phages, these may become a problem in vivo, as they may transfer superinfection resistance between different $P$. aeruginosa strains. However, the chance of temperate phage mobility causing treatment failure can be minimised with an adequately diverse cocktail as superinfection resistance is only provided to a defined range of phages [107].

\subsection{Masking Phage Receptors}

The phenomenon of masking has been shown to be mediated by glycosylation of the T4P receptor on P. aeruginosa, providing it with resistance [111]. Unlike mutations to phage receptors, glycosylation does not affect the T4P-mediated twitching motility [111]. To overcome this mechanism of resistance, phages identified during host range characterisation could be selected or trained to be capable of infecting bacteria with a glycosylated T4P. Moreover, P. aeruginosa formation of biofilms and secretion of exopolysaccharide (EPS) can facilitate masking of receptors by preventing phage penetration and receptor binding [112]. However, some phages are more capable of penetrating biofilms due to the production of matrix degradative enzymes [113].

\subsection{CRISPR-Cas}

CRISPR-cas arrays are abundant in P. aeruginosa including CF isolates [114] and can mediate immunity to specific phages [115]. The CRISPR RNA (crRNA) component of the CRISPR-cas binds complementary phage-specific DNA sequences allowing cas nucleases to cleave the recognised invader's DNA. CRISPR-cas is also capable of adaptation so that a bacterium that survives an infection can incorporate a phage's DNA into its CRISPR-cas array. Adaptation allows a bacterium to recognise and prevent subsequent infections with the same phage. The CRISPR-cas found in P. aeruginosa falls into the subtype I-F, which has four cas-associated genes (that aid crRNA production and target recognition) and two cas nuclease genes (for cleavage of target and adaptation) [114]. However, phages are able to resist CRISPR-cas resistance [116,117] and therapy uses cocktails of diverse phages, meaning it is unlikely to be the main form of resistance that evolves [94]. Nonetheless, recent in vitro work has shown that $P$. aeruginosa isolates develop CRISPR-cas resistance to single phages [94].

\subsection{Restriction-Modification (RM) Systems}

Restriction-modification (RM) systems also provide immunity to phages by recognising and cleaving DNA sequence motifs [118]. Unlike CRISPR-cas systems, these motifs are less phage-specific and not adaptive. To prevent destruction of the bacterial genome, the nucleases are often associated with methylases or other nucleotide modifiers that mark the motifs on the self-DNA, thereby preventing its cleavage [118]. Two RM-associated systems have recently been characterised including Bacteriophage Exclusion (BREX) and Defence Island Associated with Restriction-Modification (DISARM) [92]. A third system 
called DNA Degradation (DND) denotes self-DNA via sulphur addition [119]. Identification and characterisation of these RM-associated systems and their role in P. aeruginosa have not been thoroughly explored. Although genome analysis has indicated BREX and DISARM components are present in P. aeruginosa genomes [92]. Similarly, other phage resistance mechanisms, like cell-signalling coupled with abortive infection and many unknown modes of action systems, have been predicted by P. aeruginosa genomic analysis, but are yet to be functionally verified [92].

\section{Phage Evolution}

As previously mentioned, the relationship between bacteria and phages is reciprocal and the ability of phages to evolve alongside bacteria is an advantage compared to conventional antimicrobials. During DNA replication, phages undergo small mutations (Figure $2 \mathrm{~b}$ ). These are often in the receptor binding proteins, which are responsible for phage-host range and receptor recognition [120]. When multiple phages are present, as in a cocktail, evolution can occur through genome recombination (Figure 2c). Recombination creates a phage with a mosaic genome of its multiple ancestors (Figure 2c) [121]. Experimentally, evolution through recombination can produce a phage capable of infecting several initially resistant $P$. aeruginosa strains [121]. Evolution of phages can also be used to pre-adapt them to the bacterial host, suppressing the propagation of both receptor mutations [122,123] and CRISPR-cas resistance [115]. Additionally, phages can be evolved (known as training) to overcome the resistance evolved by a P. aeruginosa strain [124]. Experimentally evolved phages require stringent genome characterisation to identify any that have picked up bacterial or temperate phage genes. Phages found to contain any deleterious genes can then be excluded from being considered in therapeutic formulation.

Phages have also evolved genes that encode proteins capable of overcoming other resistance mechanisms employed by P. aeruginosa. To overcome the resistance mediated by the masking of receptors, phages have evolved to carry biofilm-degrading enzymes [113]. The enzymes breakdown the exopolysaccharide molecules in a biofilm matrix and allow more efficient penetration and phage infection [113]. Therefore, isolating and identifying phages with biofilm-degrading enzymes, through genome bioinformatic characterization, could provide preferential constituents of a cocktail for the treatment of P. aeruginosa biofilm infections.

Additionally, phages can carry anti-CRISPR genes whose products circumvent CRISPRcas resistance. Anti-CRISPRs can function through binding CRISPR-cas components, causing conformation changes that are non-functional; mimicking DNA to competitively bind CRISPR-cas, preventing recognition; binding cas nucleases, making them unable to interact and degrade phage sequences; and silencing the expression of CRISPR-cas genes [125]. Phages found to contain anti-CRISPRs, during characterisation, may be more applicable for in a therapeutic formulation to prevent CRISPR-cas resistance.

To prevent RM system resistance, phages modify their nucleotide bases. Modified nucleotides in phage genomes, such as archeosine [54], queosine [126], hypermodified thymidine, and guanine bases [127], prevent DNA motif recognition and degradation. Phages more resistant to RM resistance can be found through genomic analysis identifying those with genes capable of modifying nucleotides [54].

\section{Conclusions}

In summary, phage therapy is a promising alternative to antimicrobials in an increasingly post-antibiotic era. Specifically, this offers a solution for individuals with $C F$ where antimicrobial-resistant infections with $P$. aeruginosa drive progressive lung disease. Although resistance to phages arises, phages can also counter-evolve to overcome the mechanisms employed by bacteria. However, more work is required to understand the evolution of phage resistance in CF clinical isolates of $P$. aeruginosa and what strategies can be implemented to overcome these potential barriers. Through understanding the spectrum of mechanisms affording phage resistance and their fitness trade-offs in a CF disease relevant 
model, phage therapies, capable of increasing effectiveness and suppressing resistance, can be strategically formulated. Such a step is crucial for phage therapy to translate to a standard adjunctive therapy, alongside antimicrobials in $\mathrm{CF}$, without resistance emerging.

Supplementary Materials: The following are available online at https:/ /www.mdpi.com/2079-638 2/10/2/145/s1, Table S1: P. aeruginosa Receptor Mutations Conferring Phage-Resistance.

Author Contributions: Conceived the review topic and focus, A.V. and A.K.; conducted literature review and drafted the manuscript, A.V.; contributed to the structure and content, provided critical review, and approved the final version to be published, A.K., A.S.T., J.P.R. and S.M.S. All authors have read and agreed to the published version of the manuscript.

Funding: A.V. is funded by a Research Training Program Scholarship and an Australian Cystic Fibrosis Postgraduate Studentship Grant. A.K. is a Rothwell Family Fellow. S.M.S. is an NHMRC Practitioner Fellow.

Acknowledgments: This review was written as part of the Australian Respiratory Early Surveillance Team for Cystic Fibrosis (AREST CF). The authors thank the subjects and families for their generous contributions to the program. Full membership of the AREST CF is available at www.arestcf.org.

Conflicts of Interest: The authors declare no conflict of interest.

\section{References}

1. WHO. Prioritization of Pathogens to Guide Discovery, Research and Development of New Antibiotics for Drug-Resistant Bacterial Infections, Including Tuberculosis; World Health Organisation: Geneva, Switzerland, 2017.

2. Theuretzbacher, U.; Gottwalt, S.; Beyer, P.; Butler, M.; Czaplewski, L.; Lienhardt, C.; Moja, L.; Paul, M.; Paulin, S.; Rex, J.; et al. Analysis of the clinical antibacterial and antituberculosis pipeline. Lancet Infect. Dis. 2018, 19. [CrossRef]

3. WHO. Antibacterial Agents in Clinical Development: An Analysis of the Antibacterial Clinical Development Pipeline, Including Tuberculosis; World Health Organisation: Geneva, Switzerland, 2019.

4. O'Neill, J. Review on Antimicrobial Resistance: Tackling a Crisis forthe Health and Wealth of Nations; Wellcome Trust: London, UK, 2014.

5. CDC. Antibiotic Resistance Threats in the United States, 2019; Department of Health and Human Services, Centre for Disease Control: Atlanta, GA, USA, 2019.

6. Elborn, J.S. Cystic fibrosis. Lancet 2016, 388, 2519-2531. [CrossRef]

7. Tang, X.X.; Ostedgaard, L.S.; Hoegger, M.J.; Moninger, T.O.; Karp, P.H.; McMenimen, J.D.; Choudhury, B.; Varki, A.; Stoltz, D.A.; Welsh, M.J. Acidic pH increases airway surface liquid viscosity in cystic fibrosis. J. Clin. Investig. 2016, 126, 879-891. [CrossRef]

8. Worlitzsch, D.; Tarran, R.; Ulrich, M.; Schwab, U.; Cekici, A.; Meyer, K.C.; Birrer, P.; Bellon, G.; Berger, J.; Weiss, T.; et al. Effects of reduced mucus oxygen concentration in airway Pseudomonas infections of cystic fibrosis patients. J. Clin. Investig. 2002, 109, 317-325. [CrossRef]

9. Ramsey, K.A.; Ranganathan, S.; Park, J.; Skoric, B.; Adams, A.M.; Simpson, S.J.; Robins-Browne, R.M.; Franklin, P.J.; de Klerk, N.H.; Sly, P.D.; et al. Early respiratory infection is associated with reduced spirometry in children with cystic fibrosis. Am. J. Respir. Crit. Care Med. 2014, 190, 1111-1116. [CrossRef]

10. Gangell, C.; Gard, S.; Douglas, T.; Park, J.; de Klerk, N.; Keil, T.; Brennan, S.; Ranganathan, S.; Robins-Browne, R.; Sly, P.D.; et al. Inflammatory responses to individual microorganisms in the lungs of children with cystic fibrosis. Clin. Infect. Dis. 2011, 53, 425-432. [CrossRef]

11. Nixon, G.M.; Armstrong, D.S.; Carzino, R.; Carlin, J.B.; Olinsky, A.; Robertson, C.F.; Grimwood, K. Clinical outcome after early Pseudomonas aeruginosa infection in cystic fibrosis. J. Pediatr. 2001, 138, 699-704. [CrossRef]

12. Susannah Ahern, G.S.; Tacey, M.; Esler, M.; Oldroyd, J.; Dean, J.; Bell, S.; on behalf of the Australian Cystic Fibrosis Data Registry. The Australian Cystic Fibrosis Data Registry Annual Report, 2015; Monash University, Department of Epidemiology and Preventive Medicine: Clayton, Australia, 2017.

13. Cystic Fibrosis Foundation. Cystic Fibrosis Foundation Patient Registry 2018 Annual Data Report; Cystic Fibrosis Foundation: Bethesda, MD, USA, 2019.

14. Henry, R.L.; Mellis, C.M.; Petrovic, L. Mucoid Pseudomonas aeruginosa is a marker of poor survival in cystic fibrosis. Pediatr. Pulmonol. 1992, 12, 158-161. [CrossRef]

15. Rosenfeld, M.; Gibson, R.L.; McNamara, S.; Emerson, J.; Burns, J.L.; Castile, R.; Hiatt, P.; McCoy, K.; Wilson, C.B.; Inglis, A.; et al. Early pulmonary infection, inflammation, and clinical outcomes in infants with cystic fibrosis. Pediatr. Pulmonol. 2001, 32, 356-366. [CrossRef]

16. Emerson, J.; Rosenfeld, M.; McNamara, S.; Ramsey, B.; Gibson, R.L. Pseudomonas aeruginosa and other predictors of mortality and morbidity in young children with cystic fibrosis. Pediatr. Pulmonol. 2002, 34, 91-100. [CrossRef] 
17. Li, Z.; Kosorok, M.R.; Farrell, P.M.; Laxova, A.; West, S.E.; Green, C.G.; Collins, J.; Rock, M.J.; Splaingard, M.L. Longitudinal development of mucoid Pseudomonas aeruginosa infection and lung disease progression in children with cystic fibrosis. JAMA 2005, 293, 581-588. [CrossRef]

18. Pillarisetti, N.; Williamson, E.; Linnane, B.; Skoric, B.; Robertson, C.F.; Robinson, P.; Massie, J.; Hall, G.L.; Sly, P.; Stick, S.; et al. Infection, inflammation and lung function decline in infants with cystic fibrosis. Am. J. Respir. Crit. Care Med. 2011, $184,75-81$. [CrossRef]

19. Saiman, L. Microbiology of early CF lung disease. Paediatr. Respir. Rev. 2004, 5, S367-S369. [CrossRef]

20. Douglas, T.A.; Brennan, S.; Gard, S.; Berry, L.; Gangell, C.; Stick, S.M.; Clements, B.S.; Sly, P.D. Acquisition and eradication of P. aeruginosa in young children with cystic fibrosis. Eur. Respir. J. 2009, 33, 305. [CrossRef]

21. Ranganathan, S.C.; Skoric, B.; Ramsay, K.A.; Carzino, R.; Gibson, A.-M.; Hart, E.; Harrison, J.; Bell, S.C.; Kidd, T.J. Geographical differences in first acquisition of Pseudomonas aeruginosa in cystic fibrosis. Ann. Am. Thorac. Soc. 2013, 10, 108-114. [CrossRef]

22. Burns, J.L.; Gibson, R.L.; McNamara, S.; Yim, D.; Emerson, J.; Rosenfeld, M.; Hiatt, P.; McCoy, K.; Castile, R.; Smith, A.L.; et al. Longitudinal assessment of Pseudomonas aeruginosa in young children with cystic fibrosis. J. Infect. Dis. 2001, 183, 444-452. [CrossRef]

23. Kidd, T.J.; Ramsay, K.A.; Vidmar, S.; Carlin, J.B.; Bell, S.C.; Wainwright, C.E.; Grimwood, K. Pseudomonas aeruginosa genotypes acquired by children with cystic fibrosis by age 5-years. J. Cyst. Fibros. 2015, 14, 361-369. [CrossRef]

24. Al-Aloul, M.; Crawley, J.; Winstanley, C.; Hart, C.A.; Ledson, M.J.; Walshaw, M.J. Increased morbidity associated with chronic infection by an epidemic Pseudomonas aeruginosa strain in CF patients. Thorax 2004, 59, 334-336. [CrossRef]

25. Aaron, S.D.; Vandemheen, K.L.; Ramotar, K.; Giesbrecht-Lewis, T.; Tullis, E.; Freitag, A.; Paterson, N.; Jackson, M.; Lougheed, M.D.; Dowson, C.; et al. Infection with transmissible strains of Pseudomonas aeruginosa and clinical outcomes in adults with cystic fibrosis. JAMA 2010, 304, 2145-2153. [CrossRef]

26. Jones, A.M.; Dodd, M.E.; Morris, J.; Doherty, C.; Govan, J.R.; Webb, A.K. Clinical outcome for cystic fibrosis patients infected with transmissible Pseudomonas aeruginosa: An 8-year prospective study. Chest 2010, 137, 1405-1409. [CrossRef]

27. Ashish, A.; Shaw, M.; Winstanley, C.; Ledson, M.J.; Walshaw, M.J. Increasing resistance of the Liverpool Epidemic Strain (LES) of Pseudomonas aeruginosa (Psa) to antibiotics in cystic fibrosis (CF)—A cause for concern? J. Cyst. Fibros. 2012, 11, 173-179. [CrossRef]

28. Kidd, T.J.; Ramsay, K.A.; Hu, H.; Marks, G.B.; Wainwright, C.E.; Bye, P.T.; Elkins, M.R.; Robinson, P.J.; Rose, B.R.; Wilson, J.W.; et al. Shared Pseudomonas aeruginosa genotypes are common in Australian cystic fibrosis centres. Eur. Respir. J. 2013, $41,1091$. [CrossRef]

29. Tai, A.S.; Bell, S.C.; Kidd, T.J.; Trembizki, E.; Buckley, C.; Ramsay, K.A.; David, M.; Wainwright, C.E.; Grimwood, K.; Whiley, D.M. Genotypic diversity within a single Pseudomonas aeruginosa strain commonly shared by Australian patients with cystic fibrosis. PLoS ONE 2015, 10, e0144022. [CrossRef]

30. Wee, B.A.; Tai, A.S.; Sherrard, L.J.; Ben Zakour, N.L.; Hanks, K.R.; Kidd, T.J.; Ramsay, K.A.; Lamont, I.; Whiley, D.M.; Bell, S.C.; et al. Whole genome sequencing reveals the emergence of a Pseudomonas aeruginosa shared strain sub-lineage among patients treated within a single cystic fibrosis centre. BMC Genom. 2018, 19, 644. [CrossRef]

31. Valerius, N.H.; Koch, C.; Høiby, N. Prevention of chronic Pseudomonas aeruginosa colonisation in cystic fibrosis by early treatment. Lancet 1991, 338, 725-726. [CrossRef]

32. Wiesemann, H.G.; Steinkamp, G.; Ratjen, F.; Bauernfeind, A.; Przyklenk, B.; Döring, G.; von der Hardt, H. Placebo-controlled, double-blind, randomized study of aerosolized tobramycin for early treatment of Pseudomonas aeruginosa colonization in cystic fibrosis. Pediatr. Pulmonol. 1998, 25, 88-92. [CrossRef]

33. Gibson, R.L.; Emerson, J.; McNamara, S.; Burns, J.L.; Rosenfeld, M.; Yunker, A.; Hamblett, N.; Accurso, F.; Dovey, M.; Hiatt, P.; et al. Significant microbiological effect of inhaled tobramycin in young children with cystic fibrosis. Am. J. Respir. Crit. Care Med. 2003, 167, 841-849. [CrossRef]

34. Ratjen, F.; Munck, A.; Kho, P.; Angyalosi, G. Treatment of early Pseudomonas aeruginosa infection in patients with cystic fibrosis: The ELITE trial. Thorax 2010, 65, 286-291. [CrossRef]

35. Treggiari, M.M.; Retsch-Bogart, G.; Mayer-Hamblett, N.; Khan, U.; Kulich, M.; Kronmal, R.; Williams, J.; Hiatt, P.; Gibson, R.L.; Spencer, T.; et al. Comparative efficacy and safety of 4 randomized regimens to treat early Pseudomonas aeruginosa infection in children with cystic fibrosis. Arch. Pediatr. Adolesc. Med. 2011, 165, 847-856. [CrossRef]

36. Taccetti, G.; Bianchini, E.; Cariani, L.; Buzzetti, R.; Costantini, D.; Trevisan, F.; Zavataro, L.; Campana, S. Early antibiotic treatment for Pseudomonas aeruginosa eradication in patients with cystic fibrosis: A randomised multicentre study comparing two different protocols. Thorax 2012, 67, 853-859. [CrossRef]

37. Proesmans, M.; Vermeulen, F.; Boulanger, L.; Verhaegen, J.; De Boeck, K. Comparison of two treatment regimens for eradication of Pseudomonas aeruginosa infection in children with cystic fibrosis. J. Cyst. Fibros. 2013, 12, 29-34. [CrossRef]

38. Rasa Ruseckaite, S.A.; Ranger, T.; Dean, J.; Gardam, M.; Bell, S.; Burke, N.; on behalf of the Australian Cystic Fibrosis Data Registry. The Australian Cystic Fibrosis Data Registry Annual Report, 2017; Monash University, Department of Epidemiology and Preventive Medicine: Clayton, Australia, 2019.

39. Singh, P.K.; Schaefer, A.L.; Parsek, M.R.; Moninger, T.O.; Welsh, M.J.; Greenberg, E.P. Quorum-sensing signals indicate that cystic fibrosis lungs are infected with bacterial biofilms. Nature 2000, 407, 762-764. [CrossRef] 
40. Winstanley, C.; O’Brien, S.; Brockhurst, M.A. Pseudomonas aeruginosa evolutionary adaptation and diversification in cystic fibrosis chronic lung infections. Trends Microbiol. 2016, 24, 327-337. [CrossRef]

41. Maciá, M.D.; Blanquer, D.; Togores, B.; Sauleda, J.; Pérez, J.L.; Oliver, A. Hypermutation Is a key factor in development of multiple-antimicrobial resistance in Pseudomonas aeruginosa strains causing chronic lung infections. Antimicrob. Agents Chemother. 2005, 49, 3382. [CrossRef]

42. Smith, E.E.; Buckley, D.G.; Wu, Z.; Saenphimmachak, C.; Hoffman, L.R.; D'Argenio, D.A.; Miller, S.I.; Ramsey, B.W.; Speert, D.P.; Moskowitz, S.M.; et al. Genetic adaptation by Pseudomonas aeruginosa to the airways of cystic fibrosis patients. Proc. Natl. Acad. Sci. USA 2006, 103, 8487-8492. [CrossRef]

43. Chung, J.C.S.; Becq, J.; Fraser, L.; Schulz-Trieglaff, O.; Bond, N.J.; Foweraker, J.; Bruce, K.D.; Smith, G.P.; Welch, M. Genomic variation among contemporary Pseudomonas aeruginosa isolates from chronically infected cystic fibrosis patients. J. Bacteriol. 2012, 194, 4857-4866. [CrossRef]

44. Workentine, M.L.; Sibley, C.D.; Glezerson, B.; Purighalla, S.; Norgaard-Gron, J.C.; Parkins, M.D.; Rabin, H.R.; Surette, M.G. Phenotypic heterogeneity of Pseudomonas aeruginosa populations in a cystic fibrosis patient. PLoS ONE 2013, 8, e60225. [CrossRef]

45. Fegan, M.; Francis, P.; Hayward, A.C.; Davis, G.H.; Fuerst, J.A. Phenotypic conversion of Pseudomonas aeruginosa in cystic fibrosis. J. Clin. Microbiol. 1990, 28, 1143-1146. [CrossRef]

46. Conway, S.; Brownlee, K.; Denton, M.; Peckham, D. Antibiotic treatment of multidrug-resistant organisms in cystic fibrosis. Am. J. Respir. Crit. Care Med. 2003, 2, 321-332. [CrossRef]

47. Sordé, R.; Pahissa, A.; Rello, J. Management of refractory Pseudomonas aeruginosa infection in cystic fibrosis. Infect. Drug Resist. 2011, 4, 31-41. [CrossRef]

48. Hobbs, Z.; Abedon, S.T. Diversity of phage infection types and associated terminology: The problem with 'Lytic or lysogenic'. FEMS Microbiol. Lett. 2016, 363. [CrossRef]

49. Kutateladze, M.; Adamia, R. Phage therapy experience at the Eliava Institute. Med. Mal. Infect. 2008, 38, 426-430. [CrossRef]

50. Sulakvelidze, A.; Alavidze, Z.; Morris, J.G., Jr. Bacteriophage therapy. Antimicrob. Agents Chemother. 2001, 45, 649-659. [CrossRef]

51. Regulski, K.; Champion-Arnaud, P.; Gabard, J. Bacteriophage manufacturing: From early Twentieth-Century Processes to Current GMP. In Bacteriophages: Biology, Technology, Therapy; Harper, D.R., Abedon, S.T., Burrowes, B.H., McConville, M.L., Eds.; Springer International Publishing: Cham, Switzerland, 2018; pp. 1-31. [CrossRef]

52. Gordillo Altamirano, F.L.; Barr, J.J. Phage Therapy in the Postantibiotic Era. Clin. Microbiol. Rev. 2019, 32, e00066-18. [CrossRef]

53. Hyman, P. Phages for phage therapy: Isolation, characterization, and host range breadth. Pharmaceuticals 2019, 12, 35. [CrossRef]

54. Fernández, L.; Gutiérrez, D.; García, P.; Rodríguez, A. The perfect bacteriophage for therapeutic applications-a quick guide. Antibiotics 2019, 8, 126. [CrossRef]

55. Trend, S.; Chang, B.J.; O'Dea, M.; Stick, S.M.; Kicic, A.; WAERP; AusREC; AREST CF. Use of a primary epithelial cell screening tool to investigate phage therapy in cystic fibrosis. Front. Pharmacol. 2018, 9. [CrossRef]

56. Latz, S.; Wahida, A.; Arif, A.; Häfner, H.; Hoß, M.; Ritter, K.; Horz, H.P. Preliminary survey of local bacteriophages with lytic activity against multi-drug resistant bacteria. J. Basic Microbiol. 2016, 56, 1117-1123. [CrossRef]

57. Mattila, S.; Ruotsalainen, P.; Jalasvuori, M. On-demand isolation of bacteriophages against drug-resistant bacteria for personalized phage therapy. Front. Microbiol. 2015, 6, 1271. [CrossRef]

58. Dunne, M.; Rupf, B.; Tala, M.; Qabrati, X.; Ernst, P.; Shen, Y.; Sumrall, E.; Heeb, L.; Plückthun, A.; Loessner, M.J.; et al. Reprogramming bacteriophage host range through structure-guided design of chimeric receptor binding proteins. Cell Rep. 2019, 29, 1336-1350.e1334. [CrossRef]

59. Ando, H.; Lemire, S.; Pires, D.P.; Lu, T.K. Engineering Modular Viral Scaffolds for Targeted Bacterial Population Editing. Cell Syst. 2015, 1, 187-196. [CrossRef]

60. Yehl, K.; Lemire, S.; Yang, A.C.; Ando, H.; Mimee, M.; Torres, M.D.T.; de la Fuente-Nunez, C.; Lu, T.K. Engineering phage host-range and suppressing bacterial resistance through phage tail fiber mutagenesis. Cell 2019, 179, 459-469.e9. [CrossRef]

61. Paul, V.D.; Sundarrajan, S.; Rajagopalan, S.S.; Hariharan, S.; Kempashanaiah, N.; Padmanabhan, S.; Sriram, B.; Ramachandran, J. Lysis-deficient phages as novel therapeutic agents for controlling bacterial infection. BMC Microbiol. 2011, 11, 195. [CrossRef]

62. Kilcher, S.; Loessner, M.J. Engineering bacteriophages as versatile biologics. Trends Microbiol. 2019, 27, 355-367. [CrossRef]

63. Lenneman, B.R.; Fernbach, J.; Loessner, M.J.; Lu, T.K.; Kilcher, S. Enhancing phage therapy through synthetic biology and genome engineering. Curr. Opin. Biotechnol. 2021, 68, 151-159. [CrossRef]

64. Jurač, K.; Nabergoj, D.; Podgornik, A. Bacteriophage production processes. Appl. Microbiol. Biotechnol. 2019, 103, 685-694. [CrossRef]

65. Debarbieux, L.; Leduc, D.; Maura, D.; Morello, E.; Criscuolo, A.; Grossi, O.; Balloy, V.; Touqui, L. Bacteriophages Can Treat and Prevent Pseudomonas aeruginosa Lung Infections. J. Infect. Dis. 2010, 201, 1096-1104. [CrossRef]

66. Morello, E.; Saussereau, E.; Maura, D.; Huerre, M.; Touqui, L.; Debarbieux, L. Pulmonary bacteriophage therapy on Pseudomonas aeruginosa cystic fibrosis strains: First steps towards treatment and prevention. PLoS ONE 2011, 6, e16963. [CrossRef]

67. Alemayehu, D.; Casey, P.G.; McAuliffe, O.; Guinane, C.M.; Martin, J.G.; Shanahan, F.; Coffey, A.; Ross, R.P.; Hill, C. Bacteriophages phiMR299-2 and phiNH-4 can eliminate Pseudomonas aeruginosa in the murine lung and on cystic fibrosis lung airway cells. $m B i o$ 2012, 3, e00029-12. [CrossRef]

68. Kim, S.; Rahman, M.; Seol, S.Y.; Yoon, S.S.; Kim, J. Pseudomonas aeruginosa bacteriophage PA1Ø requires type IV pili for infection and shows broad bactericidal and biofilm removal activities. Appl. Environ. Microbiol. 2012, 78, 6380-6385. [CrossRef] 
69. Hosseinidoust, Z.; Tufenkji, N.; van de Ven, T.G. Formation of biofilms under phage predation: Considerations concerning a biofilm increase. Biofouling 2013, 29, 457-468. [CrossRef]

70. Danis-Wlodarczyk, K.; Vandenheuvel, D.; Jang, H.B.; Briers, Y.; Olszak, T.; Arabski, M.; Wasik, S.; Drabik, M.; Higgins, G.; Tyrrell, J.; et al. A proposed integrated approach for the preclinical evaluation of phage therapy in Pseudomonas infections. Sci. Rep. 2016, 6, 28115. [CrossRef]

71. Oechslin, F.; Piccardi, P.; Mancini, S.; Gabard, J.; Moreillon, P.; Entenza, J.M.; Resch, G.; Que, Y.-A. Synergistic interaction between phage therapy and antibiotics clears Pseudomonas aeruginosa infection in endocarditis and reduces virulence. J. Infect. Dis. 2016, 215, 703-712. [CrossRef]

72. Roach, D.R.; Leung, C.Y.; Henry, M.; Morello, E.; Singh, D.; Di Santo, J.P.; Weitz, J.S.; Debarbieux, L. Synergy between the host immune system and bacteriophage is essential for successful phage therapy against an acute respiratory pathogen. Cell Host Microbe 2017, 22, 38-47.e34. [CrossRef]

73. Waters, E.M.; Neill, D.R.; Kaman, B.; Sahota, J.S.; Clokie, M.R.J.; Winstanley, C.; Kadioglu, A. Phage therapy is highly effective against chronic lung infections with Pseudomonas aeruginosa. Thorax 2017, 72, 666-667. [CrossRef]

74. Fong, S.A.; Drilling, A.; Morales, S.; Cornet, M.E.; Woodworth, B.A.; Fokkens, W.J.; Psaltis, A.J.; Vreugde, S.; Wormald, P.-J. Activity of bacteriophages in removing biofilms of Pseudomonas aeruginosa isolates from chronic rhinosinusitis patients. Front. Cell. Infect. Microbiol. 2017, 7, 418. [CrossRef]

75. Chaudhry, W.N.; Concepcion-Acevedo, J.; Park, T.; Andleeb, S.; Bull, J.J.; Levin, B.R. Synergy and order effects of antibiotics and phages in killing Pseudomonas aeruginosa biofilms. PLoS ONE 2017, 12, e0168615. [CrossRef]

76. Forti, F.; Roach, D.R.; Cafora, M.; Pasini, M.E.; Horner, D.S.; Fiscarelli, E.V.; Rossitto, M.; Cariani, L.; Briani, F.; Debarbieux, L.; et al. Design of a broad-range bacteriophage cocktail that reduces Pseudomonas aeruginosa biofilms and treats acute infections in two animal models. Antimicrob. Agents Chemother. 2018, 62, e02573-17. [CrossRef]

77. Cafora, M.; Deflorian, G.; Forti, F.; Ferrari, L.; Binelli, G.; Briani, F.; Ghisotti, D.; Pistocchi, A. Phage therapy against Pseudomonas aeruginosa infections in a cystic fibrosis zebrafish model. Sci. Rep. 2019, 9, 1527. [CrossRef]

78. Olszak, T.; Danis-Wlodarczyk, K.; Arabski, M.; Gula, G.; Maciejewska, B.; Wasik, S.; Lood, C.; Higgins, G.; Harvey, B.J.; Lavigne, R.; et al. Pseudomonas aeruginosa PA5oct jumbo phage impacts planktonic and biofilm population and reduces Its host virulence. Viruses 2019, 11, 1089. [CrossRef]

79. Coulter, L.B.; McLean, R.J.C.; Rohde, R.E.; Aron, G.M. Effect of bacteriophage infection in combination with tobramycin on the emergence of resistance in Escherichia coli and Pseudomonas aeruginosa biofilms. Viruses 2014, 6, 3778-3786. [CrossRef] [PubMed]

80. Torres-Barceló, C.; Arias-Sánchez, F.I.; Vasse, M.; Ramsayer, J.; Kaltz, O.; Hochberg, M.E. A window of opportunity to control the bacterial pathogen Pseudomonas aeruginosa combining antibiotics and phages. PLoS ONE 2014, 9, e106628. [CrossRef] [PubMed]

81. Kvachadze, L.; Balarjishvili, N.; Meskhi, T.; Tevdoradze, E.; Skhirtladze, N.; Pataridze, T.; Adamia, R.; Topuria, T.; Kutter, E.; Rohde, C.; et al. Evaluation of lytic activity of staphylococcal bacteriophage Sb-1 against freshly isolated clinical pathogens. Microb. Biotechnol. 2011, 4, 643-650. [CrossRef] [PubMed]

82. Hoyle, N.; Zhvaniya, P.; Balarjishvili, N.; Bolkvadze, D.; Nadareishvili, L.; Nizharadze, D.; Wittmann, J.; Rohde, C.; Kutateladze, M. Phage therapy against Achromobacter xylosoxidans lung infection in a patient with cystic fibrosis: A case report. Res. Microbiol. 2018, 169, 540-542. [CrossRef] [PubMed]

83. Law, N.; Logan, C.; Yung, G.; Furr, C.L.; Lehman, S.M.; Morales, S.; Rosas, F.; Gaidamaka, A.; Bilinsky, I.; Grint, P.; et al. Successful adjunctive use of bacteriophage therapy for treatment of multidrug-resistant Pseudomonas aeruginosa infection in a cystic fibrosis patient. Infection 2019, 47, 665-668. [CrossRef]

84. Wright, A.; Hawkins, C.H.; Änggård, E.E.; Harper, D.R. A controlled clinical trial of a therapeutic bacteriophage preparation in chronic otitis due to antibiotic-resistant Pseudomonas aeruginosa; a preliminary report of efficacy. Clin. Otolaryngol. 2009, 34, 349-357. [CrossRef]

85. Jault, P.; Leclerc, T.; Jennes, S.; Pirnay, J.P.; Que, Y.-A.; Resch, G.; Rousseau, A.F.; Ravat, F.; Carsin, H.; Le Floch, R.; et al. Efficacy and tolerability of a cocktail of bacteriophages to treat burn wounds infected by Pseudomonas aeruginosa (PhagoBurn): A randomised, controlled, double-blind phase $1 / 2$ trial. Lancet Infect. Dis. 2019, 19, 35-45. [CrossRef]

86. Rohde, C.; Resch, G.; Pirnay, J.P.; Blasdel, B.G.; Debarbieux, L.; Gelman, D.; Górski, A.; Hazan, R.; Huys, I.; Kakabadze, E.; et al Expert opinion on three phage therapy related topics: Bacterial phage resistance, phage training and prophages in bacterial production strains. Viruses 2018, 10, 178. [CrossRef]

87. Schooley, R.T.; Biswas, B.; Gill, J.J.; Hernandez-Morales, A.; Lancaster, J.; Lessor, L.; Barr, J.J.; Reed, S.L.; Rohwer, F.; Benler, S.; et al. Development and use of personalized bacteriophage-based therapeutic cocktails to treat a patient with a disseminated resistant Acinetobacter baumannii infection. Antimicrob. Agents Chemother. 2017, 61, e00954-17. [CrossRef]

88. Zhvania, P.; Hoyle, N.S.; Nadareishvili, L.; Nizharadze, D.; Kutateladze, M. Phage Therapy in a 16-Year-Old Boy with Netherton Syndrome. Front. Med. 2017, 4, 94. [CrossRef]

89. Duplessis, C.; Biswas, B.; Hanisch, B.; Perkins, M.; Henry, M.; Quinones, J.; Wolfe, D.; Estrella, L.; Hamilton, T. Refractory Pseudomonas bacteremia in a 2-year-old sterilized by bacteriophage therapy. J. Pediatr. Infect. Dis. Soc. 2018, 7, $253-256$. [CrossRef] [PubMed]

90. Aslam, S.; Courtwright, A.M.; Koval, C.; Lehman, S.M.; Morales, S.; Furr, C.-L.L.; Rosas, F.; Brownstein, M.J.; Fackler, J.R.; Sisson, B.M.; et al. Early clinical experience of bacteriophage therapy in 3 lung transplant recipients. Am. J. Transplant. 2019, 19, 2631-2639. [CrossRef] [PubMed] 
91. Labrie, S.J.; Samson, J.E.; Moineau, S. Bacteriophage resistance mechanisms. Nat. Rev. Microbiol. 2010, 8, 317-327. [CrossRef] [PubMed]

92. Bernheim, A.; Sorek, R. The pan-immune system of bacteria: Antiviral defence as a community resource. Nat. Rev. Microbiol. 2020, 18, 113-119. [CrossRef] [PubMed]

93. Stern, A.; Sorek, R. The phage-host arms race: Shaping the evolution of microbes. Bioessays 2011, 33, 43-51. [CrossRef]

94. Broniewski, J.M.; Meaden, S.; Paterson, S.; Buckling, A.; Westra, E.R. The effect of phage genetic diversity on bacterial resistance evolution. ISME J. 2020, 14, 828-836. [CrossRef]

95. Bertozzi Silva, J.; Storms, Z.; Sauvageau, D. Host receptors for bacteriophage adsorption. FEMS Microbiol. Lett. 2016, 363. [CrossRef]

96. Chan, B.K.; Sistrom, M.; Wertz, J.E.; Kortright, K.E.; Narayan, D.; Turner, P.E. Phage selection restores antibiotic sensitivity in MDR Pseudomonas aeruginosa. Sci. Rep. 2016, 6, 26717. [CrossRef]

97. Bradley, D.E. Evidence for the retraction of Pseudomonas aeruginosa RNA phage pili. Biochem. Biophys. Res. Commun. 1972, 47, 142-149. [CrossRef]

98. Wright, R.C.T.; Friman, V.-P.; Smith, M.C.M.; Brockhurst, M.A. Cross-resistance is modular in bacteria-phage interactions. PLoS Biol. 2018, 16, e2006057. [CrossRef]

99. Wright, R.C.T.; Friman, V.-P.; Smith, M.C.M.; Brockhurst, M.A. Resistance evolution against phage combinations depends on the timing and order of exposure. mBio 2019, 10, e01652-19. [CrossRef] [PubMed]

100. Li, G.; Shen, M.; Yang, Y.; Le, S.; Li, M.; Wang, J.; Zhao, Y.; Tan, Y.; Hu, F.; Lu, S. Adaptation of Pseudomonas aeruginosa to phage $\mathrm{PaP} 1$ predation via O-antigen polymerase mutation. Front. Microbiol. 2018, 9. [CrossRef] [PubMed]

101. Latino, L.; Midoux, C.; Hauck, Y.; Vergnaud, G.; Pourcel, C. Pseudolysogeny and sequential mutations build multiresistance to virulent bacteriophages in Pseudomonas aeruginosa. Microbiology 2016, 162, 748-763. [CrossRef] [PubMed]

102. Pires, D.P.; Dötsch, A.; Anderson, E.M.; Hao, Y.; Khursigara, C.M.; Lam, J.S.; Sillankorva, S.; Azeredo, J. A genotypic analysis of five P. aeruginosa strains after biofilm infection by phages targeting different cell surface receptors. Front. Microbiol. 2017, 8. [CrossRef]

103. Le, S.; Yao, X.; Lu, S.; Tan, Y.; Rao, X.; Li, M.; Jin, X.; Wang, J.; Zhao, Y.; Wu, N.C.; et al. Chromosomal DNA deletion confers phage resistance to Pseudomonas aeruginosa. Sci. Rep. 2014, 4, 4738. [CrossRef]

104. Burgener, E.B.; Sweere, J.M.; Bach, M.S.; Secor, P.R.; Haddock, N.; Jennings, L.K.; Marvig, R.L.; Johansen, H.K.; Rossi, E.; Cao, X.; et al. Filamentous bacteriophages are associated with chronic Pseudomonas lung infections and antibiotic resistance in cystic fibrosis. Sci. Transl. Med. 2019, 11, eaau9748. [CrossRef]

105. Secor, P.R.; Sweere, J.M.; Michaels, L.A.; Malkovskiy, A.V.; Lazzareschi, D.; Katznelson, E.; Rajadas, J.; Birnbaum, M.E.; Arrigoni, A.; Braun, K.R.; et al. Filamentous bacteriophage promote biofilm assembly and function. Cell Host Microbe 2015, 18, 549-559. [CrossRef]

106. Winstanley, C.; Langille, M.G.; Fothergill, J.L.; Kukavica-Ibrulj, I.; Paradis-Bleau, C.; Sanschagrin, F.; Thomson, N.R.; Winsor, G.L.; Quail, M.A.; Lennard, N.; et al. Newly introduced genomic prophage islands are critical determinants of in vivo competitiveness in the Liverpool Epidemic Strain of Pseudomonas aeruginosa. Genome Res. 2009, 19, 12-23. [CrossRef]

107. Bondy-Denomy, J.; Qian, J.; Westra, E.R.; Buckling, A.; Guttman, D.S.; Davidson, A.R.; Maxwell, K.L. Prophages mediate defense against phage infection through diverse mechanisms. ISME J. 2016, 10, 2854-2866. [CrossRef]

108. Newton, G.J.; Daniels, C.; Burrows, L.L.; Kropinski, A.M.; Clarke, A.J.; Lam, J.S. Three-component-mediated serotype conversion in Pseudomonas aeruginosa by bacteriophage D3. Mol. Microbiol. 2001, 39, 1237-1247. [CrossRef]

109. Chung, I.-Y.; Jang, H.-J.; Bae, H.-W.; Cho, Y.-H. A phage protein that inhibits the bacterial ATPase required for type IV pilus assembly. Proc. Natl. Acad. Sci. USA 2014, 111, 11503. [CrossRef] [PubMed]

110. Tsao, Y.-F.; Taylor, V.L.; Kala, S.; Bondy-Denomy, J.; Khan, A.N.; Bona, D.; Cattoir, V.; Lory, S.; Davidson, A.R.; Maxwell, K.L. Phage morons play an important role in Pseudomonas aeruginosa phenotypes. J. Bacteriol. 2018, 200, e00189-18. [CrossRef] [PubMed]

111. Hanjeong, H.; Bondy-Denomy, J.; Marquis, H.; Sztanko, K.M.; Davidson, A.R.; Burrows, L.L. Pseudomonas aeruginosa defends against phages through type IV pilus glycosylation. Nat. Microbiol. 2018, 3, 47-52. [CrossRef]

112. Doolittle, M.; Cooney, J.; Caldwell, D. Tracing the interaction of bacteriophage with bacterial biofilms using fluorescent and chromogenic probes. J. Indust. Microbiol. 1996, 16, 331-341. [CrossRef] [PubMed]

113. Hanlon, G.W.; Denyer, S.P.; Olliff, C.J.; Ibrahim, L.J. Reduction in exopolysaccharide viscosity as an aid to bacteriophage penetration through Pseudomonas aeruginosa biofilms. Appl. Environ. Microbiol. 2001, 67, 2746-2753. [CrossRef]

114. Cady, K.C.; White, A.S.; Hammond, J.H.; Abendroth, M.D.; Karthikeyan, R.S.G.; Lalitha, P.; Zegans, M.E.; Toole, G.A. Prevalence, conservation and functional analysis of Yersinia and Escherichia CRISPR regions in clinical Pseudomonas aeruginosa isolates. Microbiology 2011, 157, 430-437. [CrossRef]

115. Cady, K.C.; Bondy-Denomy, J.; Heussler, G.E.; Davidson, A.R.; Toole, G.A. The CRISPR/Cas adaptive immune system of Pseudomonas aeruginosa mediates resistance to naturally occurring and engineered phages. J. Bacteriol. 2012, 194, 5728. [CrossRef]

116. Bondy-Denomy, J.; Pawluk, A.; Maxwell, K.L.; Davidson, A.R. Bacteriophage genes that inactivate the CRISPR/Cas bacterial immune system. Nature 2013, 493, 429-432. [CrossRef]

117. Pawluk, A.; Bondy-Denomy, J.; Cheung, V.H.W.; Maxwell, K.L.; Davidson, A.R. A new group of phage anti-CRISPR genes inhibits the type I-E CRISPR-Cas system of Pseudomonas aeruginosa. mBio 2014, 5, e00896-14. [CrossRef]

118. Tock, M.R.; Dryden, D.T.F. The biology of restriction and anti-restriction. Curr. Opin. Microbiol. 2005, 8, 466-472. [CrossRef] 
119. Wang, L.; Chen, S.; Xu, T.; Taghizadeh, K.; Wishnok, J.S.; Zhou, X.; You, D.; Deng, Z.; Dedon, P.C. Phosphorothioation of DNA in bacteria by dnd genes. Nat. Chem. Biol. 2007, 3, 709-710. [CrossRef] [PubMed]

120. Le, S.; He, X.; Tan, Y.; Huang, G.; Zhang, L.; Lux, R.; Shi, W.; Hu, F. Mapping the tail fiber as the receptor binding protein responsible for differential host specificity of Pseudomonas aeruginosa bacteriophages PaP1 and JG004. PLoS ONE 2013, 8, e68562. [CrossRef] [PubMed]

121. Burrowes, B.H.; Molineux, I.J.; Fralick, J.A. Directed in vitro evolution of therapeutic bacteriophages: The Appelmans protocol. Viruses 2019, 11, 241. [CrossRef] [PubMed]

122. Betts, A.; Vasse, M.; Kaltz, O.; Hochberg, M.E. Back to the future: Evolving bacteriophages to increase their effectiveness against the pathogen Pseudomonas aeruginosa PAO1. Evol. Appl. 2013, 6, 1054-1063. [CrossRef] [PubMed]

123. Friman, V.-P.; Soanes-Brown, D.; Sierocinski, P.; Molin, S.; Johansen, H.K.; Merabishvili, M.; Pirnay, J.-P.; De Vos, D.; Buckling, A. Pre-adapting parasitic phages to a pathogen leads to increased pathogen clearance and lowered resistance evolution with Pseudomonas aeruginosa cystic fibrosis bacterial isolates. J. Evol. Biol. 2016, 29, 188-198. [CrossRef]

124. Yang, Y.; Shen, W.; Zhong, Q.; Chen, Q.; He, X.; Baker, J.L.; Xiong, K.; Jin, X.; Wang, J.; Hu, F.; et al. Development of a bacteriophage cocktail to constrain the emergence of phage-resistant Pseudomonas aeruginosa. Front. Microbiol. 2020, 11. [CrossRef] [PubMed]

125. Trasanidou, D.; Gerós, A.S.; Mohanraju, P.; Nieuwenweg, A.C.; Nobrega, F.L.; Staals, R.H.J. Keeping crispr in check: Diverse mechanisms of phage-encoded anti-crisprs. FEMS Microbiol. Lett. 2019, 366. [CrossRef]

126. Flores, V.; Sepúlveda-Robles, O.; Cazares, A.; Kameyama, L.; Guarneros, G. Comparative genomic analysis of Pseudomonas aeruginosa phage PaMx25 reveals a novel siphovirus group related to phages infecting hosts of different taxonomic classes. Arch. Virol. 2017, 162, 2345-2355. [CrossRef]

127. Lee, Y.-J.; Dai, N.; Walsh, S.E.; Müller, S.; Fraser, M.E.; Kauffman, K.M.; Guan, C.; Corrêa, I.R.; Weigele, P.R. Identification and biosynthesis of thymidine hypermodifications in the genomic DNA of widespread bacterial viruses. Proc. Natl. Acad. Sci. USA 2018, 115, E3116. [CrossRef] 